\title{
RESEARCHPAPER
}

\section{Effect of shoot pruning on yield and quality attribute of a winter capsicum (Capsicum annum L.) crops in hills protected condition}

\author{
CHANDAN SINGH AHIRWAR ${ }^{1}$ AND N.K. HEDAU ${ }^{2}$
}

\author{
${ }^{1}$ Department of Vegetable Science, College of Agriculture, G. B. Pant University of Agriculture and Technology, \\ Pantnagar, U.S. NAGAR (UTTARAKHAND) INDIA \\ ${ }^{2}$ Vivekananda Research Institute of Hill Agriculture (ICAR), ALMORA (UTTARAKHAND) INDIA \\ Email : csrahu1126@gmail.com
}

Article Info :Received : 05.05.2014; Revised : 01.02.2015; Accepted : 15.02.2015

In greenhouse crops, fruit yield and quality can be increased by managing shoot pruning. An experiment was conducted to study the growth and flowering performance of one varieties of capsicum (Capsicum annum L.) at experimental farm Division of Vegetable, Vivekananda Research Institute of Hill Agriculture, Almora. Was studied for effects on fruit yield, fruit quality and plant growth of greenhouse grown sweet pepper (Capsicum annum L. cv. ROBUSTA) during winter 2012-2013 in Uttrakhand Hill. Fruit set was inhibited due to the high temperatures. Marketable yield (number and weight) per $\mathrm{m}^{2}$ increased linearly was greater on plants with four stems than in those with Control, Double Leader system, Triple Leader system, Fourth Leader system. Total marketable yield and extra large fruit yields per plant were greatest in the Fourth Leader system. Plants Red fruits were harvested 79 and 105 days after transplanting. The stem length and the number of nodes per stem increased linearly with the decrease in plant spacing. Stem length and number of nodes per stem were greater in single-stem than in four-stem plants. Number seeds and peal thickness of fruits and total yield were higher in four and two than in single-stem plants. Total stem weight in fourth-stem plants increased linearly with Results indicated pruned to four stems increased marketable and extra large fruit yield in a short harvest period of a winter poly house sweet pepper crop in Uttrakhand hills. Results showed that capsicum (Capsicum annum L.) yield and quality can be effectively manipulated by plant population and stem pruning, while fruit pruning had only a limited effect.

Key words : Capsicum, Capsicum annum L., Protected cultivation, Fruit quality, Stem pruning, Fruit yield

How to cite this paper : Ahirwar, Chandan Singh and Hedau, N.K. (2015). Effect of shoot pruning on yield and quality attribute of a winter capsicum (Capsicum annum L.) crops in hills protected condition. Asian J. Bio. Sci., 10 (1) : 1-5. 